\title{
Theoretical analysis on combustion features of dimethyl ether and liquefied natural gas
}

\author{
Song Xiao ${ }^{1, a}$, Xiaoyu Chen ${ }^{1, b}$, Yanna Liu ${ }^{2, c,{ }_{+}}$ \\ ${ }^{1}$ Faculty of Metallurgical and Energy Engineering, Kunming University of Science and Technology, \\ Kunming, 650093, China \\ ${ }^{2}$ Faculty of Chemical Engineering, Kunming University of Science and Technology, Kunming, \\ 650500, China \\ axskmust@163.com, ${ }^{\mathrm{b} 690569390 @ q q . c o m}, \underline{{ }^{\mathrm{c}} \mathrm{nu02004lyn@163.com}}$
}

Keywords: Dimethyl ether (DME), Liquefied natural gas (LNG), Combustion features.

Abstract. In this paper, the combustion features of dimethyl ether (DME) and liquefied natural gas (LNG) have been investigated by theoretical analysis. For the fuel consumption, the heat loss of the waste gas and the NO emission, we find that these indexes of LNG are higher than that of DME. However, the thermal efficiency of DME is better than that of LNG. In addition, the combustion products of DME do not include $\mathrm{SO}_{2}$.

\section{Introduction}

Nowadays, environment protection and energy sustainability have played essential roles in social development. However, with the development of economy, the primary energy consumption grows higher and higher. At the same time, the problems like environment pollution and resource shortage are taking seriously. Therefore, looking for new type of alternative energy has been one of the important tasks.

As an organic compound, DME is the simplest ether with the molecular formula $\mathrm{C}_{2} \mathrm{H}_{6} \mathrm{O}$ and it can be synthesized by two ways: direct or indirect. The physical properties of DME are similar to LPG, such as colorless, non-toxic, mildly anesthetic and inflammable. Besides, DME is not greenhouse gas but has a high cetane index $[1,2,3,4,5]$. DME as a new clean energy, it has high combustion efficiency, without smoke dust and particulate matter [6,7]. In addition, the emission of $\mathrm{CO}_{2}, \mathrm{SO}_{2}$ and $\mathrm{NO}_{\mathrm{x}}$ is also lower than any other fuels $[1,8,9]$. Thus, DME has attracted attention as a new energy on its production, transportation, storage and utilization $[7,10,11,12]$.

Recently, the combustion of DME has been explored at home and aboard. Lee et al. reported the combustion of DME in the scale of laboratory [13]. Subsequently, the interrelated studies about the combustion of DME have been investigated by Technical University of Denmark, AMOCO, NAVISTAR, AVL, AIST and etc. The results indicate that the nitrogen oxide is decreasing significantly when maintain the high heat efficient and dynamic property $[10,14,15]$. Because of the excellent performances of DME, Japan, Korea and many countries in Europe focus on the application of DME on engine and vehicle $[7,8,16]$. More recently, the plat flame micro combustor burning DME for thermoelectric power generation was researched [17].

In this paper, the combustion features of dimethyl ether (DME) will be studied by theoretical analysis. The results will be employed to compare with the combustion of LNG. On the foundation, we discuss the feasibility of DME replacing the LNG.

\section{Theoretical Analysis}

To facilitate comparison, a glass melting furnaces with the glass production of $1 \times 10^{3} \mathrm{~kg} / \mathrm{h}$ is use to calculate the relevant data of the combustion which uses the DME and LNG as fuel, respectively. The correlation parameters which are used in our theoretical analysis are given in Table 1.

\footnotetext{
${ }^{\dagger}$ Corresponding author: nuo2004lyn@163.com
} 
Table 1. Correlation parameters in theoretical analysis [18].

\begin{tabular}{|c|c|c|c|c|c|}
\hline Title & Symbol & Value & Title & Symbol & Value \\
\hline Empirical coefficient & $C$ & 1.1 & $\begin{array}{c}\text { Raw material } \\
\text { quantity, }[\mathrm{kg} / \mathrm{h}]\end{array}$ & $M_{O}$ & $1.2 \times 10^{3}$ \\
\hline $\begin{array}{c}\text { Air specific } \\
\text { heat, }[\mathrm{kJ} / \mathrm{kg} \cdot \mathrm{K}]\end{array}$ & $C_{\text {air }}$ & 0.91 & $\begin{array}{c}\text { Glass temperature in } \\
\text { exit, }\left[{ }^{\circ} \mathrm{C}\right]\end{array}$ & $t_{G E}$ & 1300 \\
\hline $\begin{array}{l}\text { Specific feat of glass } \\
\text { metal in } 1300^{\circ} \mathrm{C}\end{array}$ & $C_{G E}$ & 1.4 & $\begin{array}{c}\text { Ambient } \\
\text { temperature, }\left[{ }^{\circ} \mathrm{C}\right]\end{array}$ & $t_{a m b}$ & 20 \\
\hline $\begin{array}{l}\text { Specific heat of glass } \\
\text { raw materials, }[\mathrm{kJ} / \mathrm{kg} \cdot \mathrm{K}]\end{array}$ & $C_{O}$ & 0.82 & $\begin{array}{c}\text { Exhaust gas } \\
\text { temperature, }\left[{ }^{\circ} \mathrm{C}\right]\end{array}$ & $t_{F S}$ & 1300 \\
\hline $\begin{array}{c}\text { Specific heat of fuel, } \\
{[\mathrm{kJ} / \mathrm{kg} \cdot \mathrm{K}]}\end{array}$ & $C_{p, F U E L}$ & $\begin{array}{l}\text { DME:1.614, } \\
\text { LNG:2.1 }\end{array}$ & Air amount, $\left[\mathrm{m}^{3} / \mathrm{h}\right]$ & $V_{\text {air }}$ & $\begin{array}{c}\text { DME:2278, } \\
\text { LNG:2714 }\end{array}$ \\
\hline $\begin{array}{l}\text { Specific heat of exhaust } \\
\text { gas, }[\mathrm{kJ} / \mathrm{kg} \cdot \mathrm{K}]\end{array}$ & $C_{R}$ & 1.3 & $\begin{array}{c}\text { Volume fraction of } \\
\text { NO }\end{array}$ & $\varphi$ & $0.08 \%$ \\
\hline $\begin{array}{c}\text { Specific heat of } \\
\text { smoke, }[\mathrm{kJ} / \mathrm{kg} \cdot \mathrm{K}]\end{array}$ & $C_{S}$ & $\begin{array}{l}\text { DME:1.429, } \\
\text { LNG:1.433 }\end{array}$ & $\begin{array}{c}\text { Fuel } \\
\text { consumption, }\left[\mathrm{m}^{3} / \mathrm{h}\right]\end{array}$ & $V_{F U E L}$ & $\begin{array}{l}\text { DME:146, } \\
\text { LNG:261 }\end{array}$ \\
\hline $\begin{array}{l}\text { Sulfur content (calculate } \\
\left.\text { by } \mathrm{H}_{2} \mathrm{~S}\right),\left[\mathrm{mg} / \mathrm{m}^{3}\right]\end{array}$ & $G$ & $\begin{array}{l}\text { DME: } 0 \text {, } \\
\text { LNG: } 20\end{array}$ & $\begin{array}{l}\text { Volume of } \mathrm{SO}_{2} \text { in } \\
\text { smoke, }\left[\mathrm{m}^{3} / \mathrm{h}\right]\end{array}$ & $V_{G}$ & $\begin{array}{c}\text { DME:0, } \\
\text { LNG:3.439 }\end{array}$ \\
\hline $\begin{array}{l}\text { Enthalpy of fuel, } \\
{\left[\mathrm{kJ} / \mathrm{m}^{3}\right]}\end{array}$ & $h_{C, F U E L}$ & $\begin{array}{l}\text { DME: } 61700 \\
\text { LNG:37255 }\end{array}$ & $\begin{array}{c}\text { Volume of } \mathrm{NO} \text { in } \\
\text { smoke, }\left[\mathrm{m}^{3} / \mathrm{h}\right]\end{array}$ & $V_{\mathrm{NO}}$ & $\begin{array}{c}\text { DME:2.056, } \\
\text { LNG:2.38 }\end{array}$ \\
\hline $\begin{array}{c}\text { Enthalpy of } \\
\text { vapor,[kJ/kg] }\end{array}$ & $h_{f, w a t e r}$ & 4500 & $\begin{array}{c}\text { Smoke } \\
\text { volume, }\left[\mathrm{m}^{3} / \mathrm{h}\right]\end{array}$ & $V_{s}$ & $\begin{array}{c}\text { DME: } 2570 \text {, } \\
\text { LNG:2975 }\end{array}$ \\
\hline $\begin{array}{l}\text { Melting heat in } \\
\text { reaction, }[\mathrm{kJ} / \mathrm{kg} \cdot \mathrm{K}]\end{array}$ & $I$ & 630 & Air density, $\left[\mathrm{kg} / \mathrm{m}^{3}\right]$ & $\rho_{\text {air }}$ & 1.42 \\
\hline Melting rate & $M C$ & $4 \%$ & Fuel density, $\left[\mathrm{kg} / \mathrm{m}^{3}\right]$ & $\rho_{F U E L}$ & $\begin{array}{l}\text { DME: } 1.95 \text {, } \\
\text { LNG: } 0.71\end{array}$ \\
\hline Glass output,[kg/h] & $M_{G}$ & $1.0 \times 10^{3}$ & $\begin{array}{c}\text { Smoke } \\
\text { density, }\left[\mathrm{kg} / \mathrm{m}^{3}\right]\end{array}$ & $\rho_{s}$ & $\begin{array}{l}\text { DME:1.257, } \\
\text { LNG:1.236 }\end{array}$ \\
\hline
\end{tabular}

The related calculation equation is shown as follow.

Glass heat in exit of furnace:

$Q_{1}=M_{G} \cdot C_{G E} \cdot\left(t_{G E}-t_{a m b}\right)$

Melting heat in reaction in furnace:

$Q_{2}=I M_{G}$

Vaporization heat of water in raw material:

$Q_{3}=M_{G} \cdot M C \cdot h_{f, \text { water }}$

Combustion heat of fuel:

$Q_{4}=V_{F U E L} \cdot h_{C, F U E L}$

Combustion heat of organics (like antifoaming agents):

$Q_{5}=17.5 \times 10^{3} \mathrm{~kJ} / \mathrm{h}$

Physical heat of raw material:

$Q_{61}=M_{O} \cdot C_{O} \cdot t_{a m b}$ 
Physical heat of fuel:

$Q_{62}=V_{F U E L} \cdot C_{p, F U E L} \cdot \rho_{F U E L} \cdot t_{a m b}$

Physical heat of air:

$Q_{63}=V_{\text {air }} \cdot C_{\text {air }} \cdot \rho_{\text {air }} \cdot t_{\text {amb }}$

Physical heat taken into furnace:

$Q_{6}=Q_{61}+Q_{62}+Q_{63}$

Total heat taken into furnace:

$Q_{0}=Q_{4}+Q_{5}+Q_{6}$

Heat taken out by smoke:

$Q_{71}=V_{s} \cdot \rho_{s} \cdot C_{s} \cdot t_{F S}$

Heat taken out by exhaust gas in reaction:

$Q_{72}=\left(M_{O}-M_{G}\right) C_{R} \cdot t_{F S}$

Heat loss by waste gas:

$Q_{7}=C \cdot\left(Q_{71}+Q_{72}\right)$

Thermal efficiency of furnace:

$$
\eta=\frac{Q_{1}+Q_{2}+Q_{3}}{Q_{0}}
$$

According to equation (1) - equation (14), the results of theoretical calculation is shown in Table 2.

Table 2. Results of theoretical calculation.

\begin{tabular}{|c|c|c|c|}
\hline \multirow{2}{*}{ Title } & \multirow{2}{*}{ Symbol } & \multicolumn{2}{|c|}{ Value } \\
\hline & & DME & LNG \\
\hline Glass heat in exit of furnace, $[\mathrm{kJ} / \mathrm{h}]$ & $Q_{1}$ & $1792 \times 10^{3}$ & $1792 \times 10^{3}$ \\
\hline Melting heat in reaction in furnace, $[\mathrm{kJ} / \mathrm{h}]$ & $Q_{2}$ & $756 \times 10^{3}$ & $756 \times 10^{3}$ \\
\hline Vaporization heat of water in raw material, $[\mathrm{kJ} / \mathrm{h}]$ & $Q_{3}$ & $216 \times 10^{3}$ & $216 \times 10^{3}$ \\
\hline Combustion heat of fuel, $[\mathrm{kJ} / \mathrm{h}]$ & $Q_{4}$ & $9008.2 \times 10^{3}$ & $9723.6 \times 10^{3}$ \\
\hline $\begin{array}{l}\text { Combustion heat of organics(like antifoaming } \\
\text { agents), }[\mathrm{kJ} / \mathrm{h}]\end{array}$ & $Q_{5}$ & $17.5 \times 10^{3}$ & $17.5 \times 10^{3}$ \\
\hline Physical heat of raw material, $[\mathrm{kJ} / \mathrm{h}]$ & $Q_{61}$ & $19.7 \times 10^{3}$ & $19.7 \times 10^{3}$ \\
\hline Physical heat of fuel, $[\mathrm{kJ} / \mathrm{h}]$ & $Q_{62}$ & $9.2 \times 10^{3}$ & $7.8 \times 10^{3}$ \\
\hline Physical heat of air, $[\mathrm{kJ} / \mathrm{h}]$ & $Q_{63}$ & $55.2 \times 10^{3}$ & $65.7 \times 10^{3}$ \\
\hline Physical heat taken into furnace, $[\mathrm{kJ} / \mathrm{h}]$ & $Q_{6}$ & $84.1 \times 10^{3}$ & $93.2 \times 10^{3}$ \\
\hline Total heat taken into furnace, $[\mathrm{kJ} / \mathrm{h}]$ & $Q_{0}$ & $9109.8 \times 10^{3}$ & $9834.3 \times 10^{3}$ \\
\hline Heat taken out by smoke, $[\mathrm{kJ} / \mathrm{h}]$ & $Q_{71}$ & $6001.3 \times 10^{3}$ & $6850.1 \times 10^{3}$ \\
\hline Heat taken out by exhaust gas in reaction, $[\mathrm{kJ} / \mathrm{h}]$ & $Q_{72}$ & $338 \times 10^{3}$ & $338 \times 10^{3}$ \\
\hline Heat loss by waste gas, $[\mathrm{kJ} / \mathrm{h}]$ & $Q_{7}$ & $6339.3 \times 10^{3}$ & $7188.1 \times 10^{3}$ \\
\hline Thermal efficiency of furnace & $\eta$ & $30.3 \%$ & $28.1 \%$ \\
\hline
\end{tabular}




\section{Discussion}

According to the above calculations, the thermal efficiency, heat loss by waste gas, fuel consumption and the emission volume of $\mathrm{NO}$ and $\mathrm{SO}_{2}$ are illustrated in Fig. 1. The results show that the consumption volume and the heat loss by waste gas of DME are lower than that of LNG, as illustrated in Fig. 1 (a) and (b). It implies that the DME contains oxygen can reduce the requisite amount of the air, thus can decrease the volume of the waste gas emission. This result leads to the thermal efficiency of DME is higher than that of LNG, as shown in Fig. 1 (c). Since DME does not include the element S, the emission of $\mathrm{SO}_{2}$ is zero, however, $\mathrm{LNG}$ is mixture and contains the element $\mathrm{S}$, and thus $\mathrm{SO}_{2}$ exist in combustion products of LNG, as given in Fig. 1 (d). For the same volume fraction of NO, the low volume of the waste gas emission will produce the low NO emission, as shown in Fig. 1 (e). Therefore, it is feasible that DME replacing LNG in industrial thermal system.
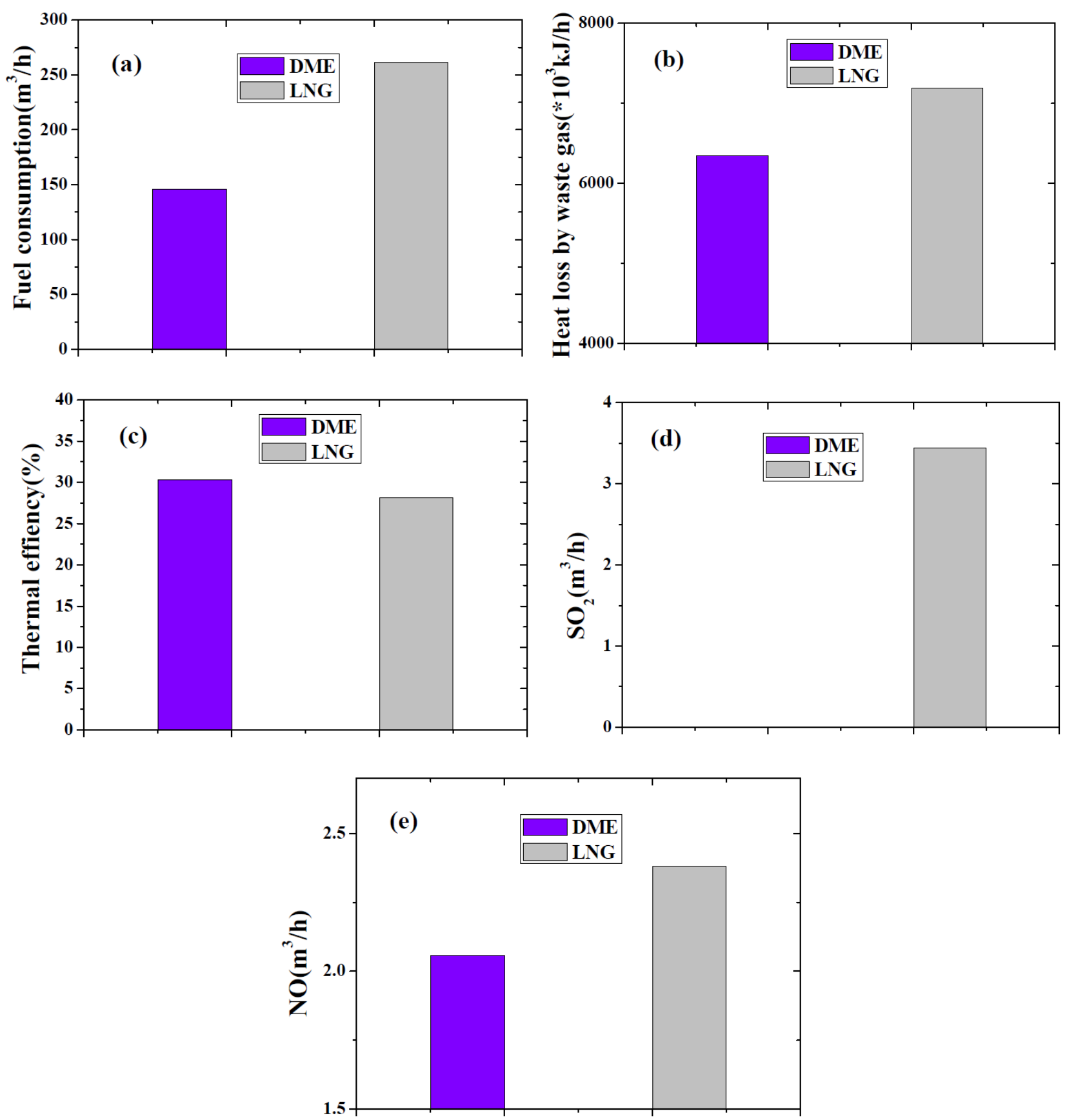

Fig.1. The comparisons diagrams with different parameters of DME and LNG. 


\section{Conclusions}

(1) For the consumption volume, NO emission and the heat loss by waste gas of DME are lower than that of LNG.

(2) The thermal efficiency of DME is higher than that of $\mathrm{LNG}$ and the emission of $\mathrm{SO}_{2}$ is zero for DME.

\section{References}

[1] S.H. Park, C.S. Lee: Progress in Energy \& Combustion Science Vol. 39 (2013), p. 147

[2] I.M. Youn, H.P. Su and H.G. Roh: Fuel Processing Technology Vol.7 (2011), p. 1280

[3] R.J. Crookes, K.D.H. Bob-Manuel: Energy Conversion \& Management Vol.48 (2007), p. 2971

[4] J. Zhang, X. Qiao and Z. Wang: Energy \& Fuels Vol.23 (2008), p. 170

[5] H.J. Kim, H.K. Suh and S.L. Chang: Energy Fuels Vol.22 (2008), p. 2851

[6] C.S. Mcenally, L.D. Pfefferle: Proceedings of the Combustion Institute Vol.31 (2007), p. 603

[7] C. Arcoumanis, C. Bae and R. Crookes: Fuel Vol.87 (2008), p. 1014

[8] M.Y. Kima, S.H. Yoona and B.W. Ryua: Fuel Vol.87 (2008), p. 2779

[9] C.H. Hwang, C.E. Lee and K.M. Lee: Energy \& Fuels Vol.23 (2009), p. 754

[10] T.A. Semelsberger, R.L. Borup and H.L. Greene: Journal of Power Sources Vol.156 (2006), p. 497

[11] J. Song, Z. Huang and X. Qiao: Energy Conversion \& Management Vol.45 (2004), p. 2223

[12] D. Cocco, V. Tola and G. Cau: Energy Vol.31 (2006), p. 1446

[13] C.L. Min, S.B. Seo and J.H. Chung: Fuel Vol.87 (2008), p. 2162

[14] E.M. Chapman, A.L. Boehman: Fuel Processing Technology Vol.89 (2008), p. 1262

[15] H.K. Suh, S.L. Chang: Fuel Vol.87 (2008), p. 925

[16] S.H. Bang, S.L. Chang: Fuel Vol.89 (2010), p. 797

[17] L.Q. Jiang, D.Q. Zhao and C.M. Guo: Energy Conversion \& Management Vol.52 (2011), p. 596

[18] B.J. Wu: Electric Power Environment Protection (In Chinese) Vol.19 (2003), p. 9 